\title{
ANCIENT STONE IMPLEMENTS FROM THE YODDA VALLEY GOLDFIELD, NORTH-EAST BRITISH NEW GUINEA.
}

By R. Etheridge, Junr., Curator.

$$
\text { (Plates vi.-vii.) }
$$

From time to time rumour's of the discovery of ancient stone implements in the auriferous alluvium of the Yodda Valley Goldfield have reached us, supposed to be those of a pre-existing race. I have been unsuccessful in finding any description of these implements or references to their discovery other than the following brief statement by Mr. C. A. W. Monckton, one of the New Guinea Resident Magistrates :-_A remarkable pestle and mortar of plainly great antiquity have been found by some miners in gold workings at a depth of 12 feet below the surface in the Yodda Valley. The mortar, which with the pestle weighed 66 lbs., was roughly ornamented with barbaric carving. . . . The pestle and mortar were discovered in the same creek as an obsidian battle axe given by me some years ago to the Hon. David Ballantine, and both would appear to be relics of a forgotten race. The natives to whom the recently found articles were shown could not make any suggestion as to their original use or purpose, and all agree that it is not the work of any now existing tribes."

No description or measurements of this interesting relic are given, which has unfortunately found its way to the British Museum. From the drawing accompanying the above remarks it appears to be a depressed, hardly round piece of rock hollowed in the centre, and scalloped round the edge. Two other objects, a pounding-mortar and a nondescript implement, are in this Museum, also from the Yodda Valley Goldfield, presented by Mr. A. L. Joubert.

${ }^{1}$ Monckton-Brit. N. Guinea. Ann. Report for Year ending 30th June, 1904 (1905); Commonwealth Parl. Papers, 1905, No. 1, C. 7001, p.31, 4th pl. 
The mortar (Plate vi., fig. 1) weighs $30 \mathrm{lbs}$, and consists of mica schist. It is more or less heraldic shield-shaped in outline, truncated at the base, and with its upper outer edge broad and bevelled outwards The length is fourteen inches, the width twelve, and five inches at the deepest point. 'I he interior has been unequally worn, the deeper hollow at the truncated end, the smoothed or ground surface being very apparent. In common with the next object to be noticed, it was found at a depth of eight feet from the surface, but whether the two were discovered together I am unable to say. We have no stone mortars from New Guinea for comparison with this ancient implement, but from the Marshall Bennett Islands and from Woodlark Island we possess large, heavy, and slightly concave (on one surface) stones used for sharpening stone adze-heads on ; these are much rougher, more primitive, and less concave than the Yodda Valley mortar. The nearest illustration I have seen is that of a rough stone mortar from the Solomon Islands figured . by Edge-Partington. ${ }^{2}$

The second specimen (Plate vi., fig. 2) presented by Mr. Joubert might at first sight be put aside as fortuitous, but I believe it to have been manufactured. It is a piece of clay-stone, ten inches long, four inches wide, and generally speaking dagger-shaped and compressed; it weighs 3 lbs. It is flattened on one face and somewhat arched on the other. When viewed sideways there is nothing of moment to remark, but when looked at on either face there is an unmistakable conventional resemblance to the human form. At any rate this is so to the eye of a student accustomed to follow the hundred-and-one conventionalised modifications under which it and other natural objects are concealed in Western Pacific carvings and drawings. As to the figure itself, above is a rounded (in outline) compressed portion answering to a head, cut off by a neck and unsymmetrical shoulders from the long pointed body, in which there is no division into limbs. On the arched aspect of the implement is a central longitudinal ridge. The object of this must remain unknown; it is certainly not a pounder.

Certain stones used by the New Caledonians as a fetish, or charm, for success in fishing, or buried by the sorcerer in yam plantations to render the ground fruitful, bear a general resemblance. ${ }^{3}$ We have in our collection a semi-human wooden figure from Easter Island terminating below in an undivided pointed and rounded base.

2 Edge-Partington-Atlas, 2nd Series, pl. 111, f. 5.

${ }^{3}$ Edge-Partington-Atlas, 3rd Series, pl. 71, f. 4 and 5. 
I have now to call attention to a very extraordinary figure lent to me by the well known Sydney collector Mr. P. G. Black, and of which I have been permitted to take a copy for the Museum collection. This animal figure (Plate vii., figs. 1 \& 3 ) was discovered in a village towards the head-waters of the Giriwo River, at from 3,000 to 4,000 feet above sea-level. Mr. Black informs me that the Giriwo River, which does not yet appear in any of our maps, is on the Buna Bay to Yodda Valley Road, and such being the case, it is evidently not a tributary of the Yodda River, but rises to the eastward in the same high country as that in which the northern tributaries of the Yodda rise; most probably the Giriwo River falls into Buna Bay. As to the figure, Mr. Black writes me thus :- "This image must evidently have come into the possession of the present race of natives by accident and probably some considerable time ago, for it clearly belongs to the same age as the discoveries made in the Yodda Valley. The natives evidently thought a good deal of it . . . . and it evidently belonged to the village, and to no one man in particular."

The object represents a rude animal figure, fourteen and a half inches long by six inches wide, and weighs $17 \mathrm{lbs}$. The head, arms, and upper part of the body gemerally are tolerably well formed, the head thrust forward and inclined rather to one side; the fore-arms are also bent forward and the indistinct hands closed over what would be the abdomen, but is simply an obtuse obconical pivot-like termination. When viewed from the side the head is seen to be of a very low type, certainly not human, but possibly marsupial. The antero-posterior outline of the head in the middle line is nearly flat at the top but arched facially, and the nose flattened with small nostrils and mouth. There is no chin, the under surface being flat, with a central throat-lappet. The eyes are large and prominent, the ears small, depressed, and set far back, in fact represented simply by low prominences with central depressions; the neck behind is represented by a projecting roll. When viewed from behind the shoulders are high and narrow, and the central or vertebral region raised and rounded, and terminating below in a short coxygeal projection; the arms in their great length are decidedly simian. The stone is a hornblendic rock, and the tool marks are plainly visible.

The use of this object is beyond speculation; some have suggested it to be a pestle or pounder, although I hardly think it is of this nature. When seen from the front, back, or side in profile, there is no suggestiveness about it, except that the head presents a rude resemblance to that of the Spotted Cuscus (Phalanger maculatus, Geoff.). On the other hand, if laid hori- 
zontally on the back, the phallic nature is self-evident, and I think it much more likely to have been an emblem (priapus or lingam) of that nature.

Although not found in the Yodda Valley, we have another stone of equal interest (Plate vi., fig. 3), but it would not surprise me to find it originally came from that area. It is a heavy slab of basalt bearing an excellent example of spiral incising. It is from Boianai, Goodenough Bay, North-east Coast of New Guinea, and was presented by Mr. F. de S. Buchanan, but whether disinterred or found on the surface I am unable to say; the origin is said to be quite unknown to the present natives. The object as a whole was called by the latter wakima kirukiru mana, and the spiral design giripipina. The slab measures sixteen inches long, by eleven inches wide, and six deep, and weighs $62 \mathrm{lbs}$. The incised spiral, a very perfect one, is ten and a half inches in diameter and consists of six whorls. It is quite unnecessary to dilate here on the widespread occurrence of this form of petroglyph in America and Europe, and even in Australia as rockshelter pictographs and churinga ornamentation. Spiral motive does not appear to be common in New Guinea present day decorative art. It is found on some Trobriand lime spatulas and Buruburu drums and shields from the Papuan Gulf District.

In $1905 \mathrm{Mr}, \mathrm{P}$. J. Money, a member of the New Guinea Anglican Mission, presented us with a large quantity of pottery fragments and incised shell-pieces, found on digging into ancient village mounds at his station of Wanegela. The incised motive on this pottery is quite different to that on any of the existing New Guinea pottery, and to Mr. Money the present natives disclaim all knowledge of it, and the fabricators. The interesting point, however, in connection with the present subject is the occurrence of shell-pieces (Cones) bearing beautiful examples of spiral incision-work! Referring to this find, Mr. Monckton says - "In some excavations carried out by the Mission and natives at Rainu, in Collingwood Bay, an interesting discovery was made of an old village site of a forgotten people and a quantity of broken and ancient pottery found, of curious and unique design and shapes. The pottery was much superior to any now made or in use, and there is no tradition or record of the people by whom it was made. Among human remains at a depth of 4 feet, two fragments of carved shell were found, placed, I think, originally in graves. The art of carving on hard shells is not now practised." This discovery of ancient pottery and

Monckton-Loc. cit., p. 33. 
carved shell work has been since described, and some examples figured by Dr. Rudolf Poch, ${ }^{5}$ of Vienna

I think it may now fairly be conceded there is ample evidence of the existence of an extinct, or at any rate former population in Eastern New Guinea, of a highly interesting nature. Although the information to hand is not sufficient to prove the hypothesis, it is possible that this pottery and the buried works of art of the Yodda Valley Goldfield are the productions of one and the same people.

${ }^{5}$ Poch-Mittl. Anthrop. Gesellsch. Wein, xxxvii., 1907, p.67-71, f. 7 and 8. 


\section{$2 \mathrm{BHL}$ Biodiversity Heritage Library}

Etheridge, Robert. 1908. "Ancient stone implements from the Yodda Valley goldfield, north-east British New Guinea." Records of the Australian Museum 7, 24-28. https://doi.org/10.3853/j.0067-1975.7.1908.946.

View This Item Online: $\underline{\text { https://www.biodiversitylibrary.org/item/33721 }}$

DOI: https://doi.org/10.3853/j.0067-1975.7.1908.946

Permalink: https://www.biodiversitylibrary.org/partpdf/17636

\section{Holding Institution}

MBLWHOI Library

\section{Sponsored by}

MBLWHOI Library

\section{Copyright \& Reuse}

Copyright Status: NOT_IN_COPYRIGHT

This document was created from content at the Biodiversity Heritage Library, the world's largest open access digital library for biodiversity literature and archives. Visit BHL at https://www.biodiversitylibrary.org. 